\title{
Bacteriological Evaluation of Retailed Broiler Chicken Carcasses in Port-Said Province, Egypt
}

\author{
AbdeIrahman H.A, Rana M Omar and Heba M. A. Shaheen \\ *Faculty of Veterinary Medicine, Suez Canal University
}

\section{Abstract}

A total of 80 random samples of freshly slaughtered and chilled broiler chicken carcasses (40 of each) were collected from different private small-scale manual poultry processing shops and local retailers in Port Said Province-Egypt during the period extended from January to May 2020. All samples were subjected to bacteriological examination to evaluate the quality and safety of dressed chicken carcasses. The obtained results revealed that the incidence rates of Escherichia coli, salmonella and campylobacter in the examined freshly slaughtered broiler chicken carcasses samples were 65\%, 50\%, and $55 \%$, respectively, while the aerobic colony counts ranged from $1.5 \times 10^{5}$ to $1.1 \times 10^{6}$, with a mean value of $3.2 \times 10^{5} \pm$ $4.2 \times 10^{4} \mathrm{cfu} / \mathrm{cm}^{2}$, respectively. Meanwhile, the incidence rates of $E$. coli, salmonella and campylobacter in the examined air chilled broiler chicken carcasses samples were $75 \%, 35 \%$, and $40 \%$, respectively, and the aerobic colony counts were ranged from $3 \times 10^{6}$ to $1.9 \times 10^{8}$, with a mean value of $4.1 \times 10^{7} \pm 1.1$ $\times 10^{7} \mathrm{cfu} / \mathrm{cm}^{2}$, respectively. From the obtained results, it was concluded that dressed freshly slaughtered and air chilled broiler chicken carcasses could be contaminated with a variety of bacteria which reflected the standard of hygiene under which these carcasses were slaughtered, handled and stored in addition to the probable public health hazards.

Key words: Slaughtered chicken, ACC, salmonella, E. coli, campylobacter

\section{Introduction}

Chicken meat consumption contributes to improve the quality of the diet among developed and developing countries, it contains high protein content, unsaturated fats, vitamins, and minerals (FAO, 2010). There is an association between chicken consumption within a balanced diet and good health. Whereas, the consumption of chicken meat as part of a vegetable-rich diet, 
associated with a risk reduction of developing obesity, cancer, cardiovascular diseases, and type 2 diabetes mellitus (Marangoni et al., 2015). Both chicken muscle and skin considered excellent substrates for supporting the growth of a wide variety of microorganisms due to high moisture content and nitrogenous compounds (ICMSF, 2005). Slaughtered chicken carcasses harbored a tremendous number of bacteria in the digestive tract, lungs, skin, feathers, and feet. In addition to that, the carcasses were contaminated from slaughterhouses, methods of slaughtering and liquids used in broiler processing. The improper storage during transportation and marketing can facilitate the multiplication of bacteria (Rouger et al., 2017). Moreover, all stages of broiler carcasses production stages provide opportunities for carcass contamination with Salmonella, Campylobacter, and E. coli (Ibrahim et al., 2015). The majority of consumers purchased broiler meat from the small retail outlets where chickens are slaughtered and dressed under unhygienic conditions (Das and Biswas, 2003). The prevailing conditions of the most of small-scale broiler processing units are not satisfactory for the hygienic standards because of lack of proper infrastructure, unsanitary conditions during processing, prolonged use of scald water, improper evisceration and a shortage and dilate of refrigeration after chicken carcasses processing (Yashoda et al., 2001).

The presence of pathogenic and spoilage microorganisms in chicken meat is considered as one of the major challenges and concerns for suppliers, consumers, and public health officials worldwide (Chaiba et al., 2007). Whereas, Enteropathogenic Escherichia coli usually causes severe diarrhea and gastrointestinal illness (Smith and Fratamico, 2005). In addition to that, the consumption of poorly cooked with chicken meat contaminated with salmonella can cause severe health hazards (Rani et al., 2017). Also, campylobacter food poisoning which characterized by watery diarrhea, acute enteritis, and several complications, (Boysen et al., 2014).

The contamination of broilers chicken meat with food poisoning bacteria resulted in economic losses to retailers and processors. Therefore, this study was conducted to evaluate the bacteriological quality of freshly and air chilled broiler chicken carcasses purchased from small scale manual poultry processing shops and local retailers in Port 
Said province via determination of ACC, and detection of Escherichia coli, Salmonella and Campylobacter.

\section{Materials and Methods:}

A total of 80 samples of broiler chicken carcasses including; 40 of freshly slaughtered broiler chicken carcasses and 40 of air chilled chicken carcasses $\left(4-10^{0}\right.$ C) were randomly collected from different private small scale manual poultry processing shops and local retail shops in Port Said province.

\section{Preparation of samples:} According to Thomas (1978), the technique recommended by USDA/FSIS (1996) and Thiessen (2000), the method of measuring the approximate internal, external and total surface area of commercially eviscerated poultry carcasses was used. After determining the weight, each carcass was rinsed with $400 \mathrm{ml}$ of $0.1 \%$ peptone water, the carcass was allowed to drain for 15 seconds. Tenth fold serial dilutions up to $10^{-8}$ were prepared for determining ACC and detection E. coli. For salmonella and campylobacter $25 \mathrm{ml}$ of rinse fluid was preenriching in $225 \mathrm{ml}$ of sterile buffered peptone water for $18 \mathrm{~h} \pm$ 2 at $37^{\circ} \mathrm{C}$ for salmonella and Preston selective enrichment broth under micro aerobic condition for campylobacter detection. Data from carcass rinse fluids, expressed as colony forming units (CFU) / $\mathrm{ml}$, was converted to counts $/ \mathrm{cm}^{2}$ by using the formula published in FSIS / USDA microbial baseline survey (USDA, 1996).

1. Determination of ACC as described by ISO (48331:2013).

2. Detection of Escherichia coli as described by ISO (166492:2001).

3. Detection of salmonella as described by ISO (65791:2017).

4. Detection of campylobacter as described by $\mathbf{I S O}$ (102721:2017).

\section{Results and Discussion}

Food poisoning caused by consumption of contaminated chicken meats had a serious impact on consumer's health, as well as economic losses due to the cost of medical care and social costs (Alvarez-Astorga et al., 2003).

1. Aerobic colony counts of freshly slaughtered broiler carcasses:

Aerobic colony count used as an indicator of the hygienic measures applied during processing, storage, and marketing of food products (APHA, 2001). The data recorded in Table (1) revealed that the minimum, maximum and mean value \pm SE of aerobic colony count of the examined freshly slaughtered were ranged 
from1.5 $\times 10^{5}$ to1. $1 \times 10^{6}$, with a mean value $3.2 \times 10^{5} \pm 4.2 \times$ $10^{4} \mathrm{cfu} / \mathrm{cm} 2$ while in air chilled broiler carcasses samples they were ranged from $3 \times 10^{6}$ to 1.9 $\times 10^{8}$, with a mean value of $4.1 \times$ $10^{7} \pm 1.1 \times 10^{7} \mathrm{cfu} / \mathrm{cm}^{2}$. The recorded result for freshly slaughtered was nearly compatible with Hmd et al. (2017) who examined 50 of chicken carcasses and found that aerobic plate count ranged from $2.4 \times 10^{4}$ to $1.2 \times 10^{6}$, with a mean value $5.4 \times 10^{5} \pm 9.2 \times 10^{4} \mathrm{cfu} / \mathrm{g}$. On the other hand, this result was relatively lower than those found by Mira and Eskander (2007) who found that the mean value of aerobic plate count was $6.1 \pm 0.1$ $\log 10 \mathrm{cfu} / \mathrm{g}$ in the collected samples, also the obtained result was relatively higher than those determined by Zhang et al. (2012) who recorded that the aerobic bacterial count by rinse method in the collected samples of broiler carcasses was $4.60 \pm 0.04 \log \mathrm{cfu} / \mathrm{cm}^{2}$. By matching the results of aerobic plate count with ES (2005), only $10 \%$ of freshly slaughtered broiler chicken carcasses samples was exceed the PL this result may attributed to the unsanitary conditions and high ambient temperature in poultry processing shops, and the unhygienic condition of handlers (Bailey et al., 1987). For air chilled carcasses, the obtained results were nearly similar to that result obtained by Uysal et al. (2020) who found that total ACC of whole broiler carcasses after 10 days of the cold storage at $4^{\circ} \mathrm{C}$ was $7.88 \pm 0.58 \log 10$ $\mathrm{cfu} / \mathrm{ml}$, while these results were relatively lower than those results found by Nossair et al. (2015) who recorded that the APC ranged from $3 \times 10^{4}$ to $3.5 \times 10^{9}$, with a mean value $3.5 \times 10^{8} \pm 8.2 \times 10^{7} \mathrm{cfu} / \mathrm{g}$. On the other hand, these results were relatively higher than that obtained by Giombelli et al. (2013) who recorded that the aerobic plate count of broiler carcasses was $4.75 \pm 0.28 \mathrm{log}$ $\mathrm{cfu} / \mathrm{ml}$. By matching this result with ES (2005), it revealed that $100 \%$ of chilled broiler chicken carcasses had aerobic plate count above the permissible limit, these results could be explained by the cross contamination and fluctuating refrigeration temperatures which facilitated the growth of microorganisms (Sharma and Chattopadhyay, 2015).

The data recorded in Table (2) revealed that the incidence of Escherichia coli, salmonella and campylobacter in the examined freshly slaughtered and air chilled broiler carcasses samples which were $65 \%, 50 \%$ and $55 \%$, and $75 \%, 30 \%$ and $40 \%$, respectively. The obtained results for E.coli in freshly slaughtered chicken carcasses was nearly similar to this 
reported by Seol et al. (2012) who determined the incidence of E. coli in chicken carcasses by using whole-chicken rinsing technique was $60.36 \%$.On the other hand, this result was incompatible with the result determined by Yashoda et al. (2001) who couldn't detect $E$. coli in hygienically processed carcasses, while it was relatively lower than that obtained by Nossair et al. (2015) who isolated $E$. coli from freshly slaughtered chicken carcasses samples with an incidence of $80 \%$.

The result of Escherichia coli in air chilled chicken was nearly similar to that result reported by Nossair et al. (2015) who isolated E. coli from chilled chicken carcasses samples with an incidence of $76 \%$, while this result was relatively lower than those detected by Hmd et al. (2017) who isolated E. coli from chilled chicken carcasses samples by incidences of $88 \%$. The presence of Escherichia coli is considered an indicator of direct or indirect fecal contamination during processing. Also the presence of E. coli in chilled chicken samples could be explained by cross contamination, bad hygienic conditions of vendors, and the improper storage condition (Naaz et al., 2020). For salmonella, the obtained results in freshly slaughtered chicken carcass was similar to that result obtained by Guergueb et al. (2014) who found that the prevalence of salmonella in chicken carcasses collected from slaughterhouses in the Biskra region, Algeria was $50 \%$, also it was nearly similar to that obtained by Shafini et al. (2017) who determined the prevalence of salmonella in raw chicken samples sold from butcher shops in Malaysia by whole carcass rinse method was $54.2 \%$.On the other hand, this result disagreed with those reported by Shaltout (2009) who failed to detect Salmonella spp. in the examined samples. By comparing this result with $E S 1651$ (2005), it revealed that $50 \%$ of freshly slaughtered broiler samples were not compatible to Egyptian organization for standardization and quality control for chicken carcasses. In air chilled chicken carcasses, the incidence of salmonella was nearly similar to that obtained by Alaliet al. (2012) who found that the prevalence of salmonella in whole chilled broiler chicken carcasses samples was $36.1 \%$, while it was relatively lower than that obtained by Donado et al. (2012) who determined the incidence of salmonella in chilled chicken samples was $42 \%$. By matching the results with ES 1651 (2005), it was clear that $35 \%$ of chilled broiler samples were not compatible to 
Egyptian organization for standardization and quality control for chicken carcasses. The contamination of samples with salmonella might be attributed to unhygienic sources of carcasses which packed for sale or storage, cross contamination during handling preparation, and improper refrigerated .For campylobacter, the obtained results in freshly slaughtered chicken carcasses was nearly similar to that found by Kagambèga etal. (2018) who determined the prevalence of campylobacter in slaughtered chicken carcasses was $50 \%$, while it was relatively lower than those detected by Nohra et al. (2018) who recorded that the prevalence of campylobacter spp.in whole chicken carcasses rinse samples was 60/72 (83.3\%), On the other hand, these results were relatively higher than those found by Khalafalla et al. (2015) who found that the prevalence of campylobacter jejuni in fresh chicken broiler carcasses was $44 \%$. On the other hand, the obtained result of campylobacter in air chilled broiler carcasses was nearly similar to the results found by Oyarzabal et al. (2005) who determined that the prevalence of campylobacter in chilled broiler carcasses rinse samples was $45.4 \%$,while it was relatively higher than those obtained by Lindblad et al. (2006) who found that the incidence of campylobacter in chilled broiler chickens carcasses was $16 \%$. The obtained results were relatively lower than those detected by Gonsalves et al. (2016) who revealed that the frequency rates of campylobacter spp. in chilled broiler carcass samples were $100 \%$. The contamination of broiler with campylobacter could be explained by the unhygienic condition, cross contamination, and incorrect storage conditions, these result might be referred to contaminated birds, improper handling practices, incorrect plucking and evisceration, and low scalding temperature, (Seliwiorstow et al., 2016).

Table (1): Statistical analytical results of aerobic colony count $\mathrm{cfu} / \mathrm{cm}^{2}$ of the examined samples of freshly slaughtered and Air chilled broiler chicken carcasses $(\boldsymbol{n}=\mathbf{4 0})$

\begin{tabular}{|c|c|c|c|c|c|c|}
\hline Broiler & \multirow{2}{*}{\begin{tabular}{c}
\multirow{2}{*}{ Marcasses } \\
Min.
\end{tabular}} & Max. & \multirow{2}{*}{ Mean } & \multirow{2}{*}{$\mathbf{\text { SEM }}$} & \multicolumn{2}{|c|}{ Samples exceedPL } \\
\cline { 5 - 7 } & & & & & No & $\mathbf{\%}$ \\
\hline Fresh & $1.5 \times 10^{7}$ & $1.1 \times 10^{6}$ & $3.2 \times 10^{7}$ & $4.2 \times 10^{4}$ & 4 & $10 \%$ \\
\hline Air chilled & $3 \times 10^{6}$ & $1.9 \times 10^{8}$ & $4.1 \times 10^{7}$ & $1.1 \times 10^{7}$ & 40 & $100 \%$ \\
\hline
\end{tabular}

\section{PL: Permissible Limits}


ES 1651:(2005) stated that aerobic colony count must not exceed $10^{5}$ cfu/gm.

Table (2): Incidence of Escherichia coli, salmonella and campylobacter in the examined samples offreshly slaughtered and air chilled broiler chick en carcasses $(\boldsymbol{n}=\mathbf{4 0})$

\begin{tabular}{|c|c|c|c|c|}
\hline \multirow{2}{*}{ Bacterial profile } & \multicolumn{2}{|c|}{ Freshly slaughte red } & \multicolumn{2}{c|}{ Air chilled } \\
\cline { 2 - 5 } & No & \% & No & \% \\
\hline Escherichia coli & 26 & 65 & 30 & 75 \\
\hline Salmonella & 20 & 50 & 14 & 35 \\
\hline Campylobacter & 22 & 55 & 16 & 40 \\
\hline
\end{tabular}

\section{Conclusion:}

In this study it was proved that broiler meat harbored high microorganisms with significant risk of meat spoilage because of unsanitary conditions, cross contamination, and poor personal hygiene conditions during processing, handling, packaging, storage, distribution and selling. Therefore, enhance the microbiological quality and increasing the shelf life of broiler meat is essential by implementation of strict sanitation practices and good hygienic procedures throughout the chain of broiler chicken processing.

\section{REFERENCES}

Alali, W. Q.; Gaydashov, R.; Petrova, E.; Panin, A. ; Tugarinov, O.; Kulikovskii, A.; Mamleeva, D.; Walls, I. and Doyle, M. P. (2012): Prevalence of Salmonella on retail chicken meat in Russian federation. Journal of Food Protection, Vol. 75, No. 8, 2012, Pages 1469-1473. doi: 10.4315/0362-028X.JFP-12-080

Alvarez-Astorga, M.; Capita, R.; Alonso-Calleja, C.; Moreno, B.; del Camino García-Fernánde z, M.(2003): Occurrence of Salmonellae in retail chicken carcasses and their products in Spain. International Journal of Food Microbiology, 2003 Mar 15; 81(2):169-73.

American Public Health Association (APHA) (2001): Compendiums of methods for microbiological examination of foods. $4^{\text {th }}$ ed. $1^{\text {st }}, \quad \mathrm{NW}$ Washington DC.365-366.

Bailey, J. S.; Thomson, J. E. and Cox, N. A. (1987): Contamination of poultry during processing. pp. 193-211. In F. E. Cunningham and N. A. Cox (eds.). The Microbiology of Poultry Meat Products. Academic Press, New York, NY. 
Boysen, L.; Rosenquist, H.; Larsson, J.T.; Nielsen, E.M.; Sørensen, G.; Nordentoft, S. and Hald, T.(2014): Source attribution of human campylobacteriosis in Denmark. Epidemiology and Infection Journal. 142(8):1599-608.

Chaiba, A.; Rhazi, F.F.; Chahlaoui, A.; Soulaymani, B.R. and Zerhouni, M. (2007): Microbiological quality of poultry meat on the Meknès market (Morocco). International journal of food safety; 19: 67-71.

Das, A.K. and Biswas, S. (2003): Effect of slaughtering methods on microbiological quality of chicken. Journal of veterinary public health; 101: 147-152.

Donado, G. P.; Clavijo, V.; Leon, M.; Tafur, M.A.; Gonzales, S., Hume, M.; Alali, W.; Walls, I.; Lo Fo Wong, D. M. and Doyle, M. P. (2012): Prevalence of Salmonella on retail broiler chicken meat carcasses in Colombia. Journal of Food Protection, 75(6):11348.

ES No. 1651 (2005): Egyptian Organization for Standardization and Quality Control for poultry and chilled rabbit chicken carcasses.

FAO' Food and Agriculture Organization (2010): Poultry meat and eggs: Agribusiness handbook. investment centre division, Rome, Italy, Pages: 77.

Giombelli, A.; Cavani, R. and Gloria, M. B. A. (2013): Evaluation of three sampling methods for the microbiological analysis of broiler carcasses after immersion chilling. Journal of Food Protection, Vol. 76, No. 8, 2013, Pages 1330-1335. doi: 10.4315/0362-028X.JFP-13-004.

Gonsalves, C. C.; Borsoi, A.; Perdoncini, G.; Rodrigues, L.B.and do Nascimento, V. P. (2016): Campylobacter in broiler slaughter samples assessed by direct count on mCCDA and Campy-Cefex agar. Brazilian Journal of Microbiology, 2016 Jul-Sep; 47(3): 764-769. Doi: 10.1016/j.bjm.2016.04.025.

Guergueb, N.; Alloui, N.; Ayachi, A. and Bennoune, $O$. (2014): Effect of slaughterhouse hygienic practices on the bacterial contamination of chicken meat. Scientific Journal of Veterinary Advances, 3(5) 7176. Doi: 10.14196/sjvs. v3i5.1405.

Hmd, R. M.; Samaha, I. A. and Nossair, M. A. (2017): microbiological evaluation of retailed broiler chicken carcasses in Alexandria province. Alexandria Journal of Veterinary Sciences. Vol. 54 (2): 91- 98. July 2017

DOI: 
Ibrahim, H. M.; Amin, R. A.; El-Shater, M. A. and Hafez, S. M. (2015): Bacteriological evaluation of freshly slaughtered chicken carcasses. Benha Veterinary Medical Journal, VOL. 28, NO. 2:74-82.

ICMSF"

Commission

Microbiological Specifications for Foods (2005): Microorganisms in Foods. 6. Microbial ecology of Food Commodities.

Kluwer

Academic/ Plenum Publishers, New York, USA.

ISO

International

Organization for Standardization (2001) (ISO 16649-2: 2001): Microbiology of food and animal feeding stuffs: Horizontal method for the enumeration of $\beta$-glucuronidasepositive Escherichia coli, Part 2: Colony count technique at $44^{\circ} \mathrm{C}$ using 5-bromo-4-chlor o3indolyl Beta-D-glucuronide. International Organization for Standardization. Geneva, Switzerland.

ISO

Organization

International

Standardization (2013) (ISO 4833-1: 2013): Microbiology of the food chain: Horizontal methods for the enumeration of microorganisms, Part 1: Colony count at $30^{\circ} \mathrm{C}$ by the pour plate technique, 1st edition, International Organization for
Standardization.

Geneva, Switzerland.

ISO

International

Organization for Standardization (2017) (ISO 10272-1: 2017): Microbiology of the food chain: Horizontal method for detection and enumeration of Campylobacter species. Part 1: Detection method. ISO 10272- 1 (E) International Organization for Standardization. Geneva, Switzerland.

ISO International

Organization for Standardization (2017) (ISO 6579-1:2017): Microbiology of the food chain: Horizontal method for the detection, enumeration and serotyping of Salmonella, Part 1: Detection of Salmonella species. International Organization for Standardization.

Geneva,

Switzerland.

Kagambèga, A.; Thibodeau, A.; Trinetta, V.; Soro, D. K.; Sama, F. N.; Bako, É.; Bouda, C. S.; N'Diaye, A. W.; Fravalo, P.andBarro, N.(2018): Salmonella spp. and Campylobacter spp. in poultry feces and carcasses in Ouagadougou, Burkina Faso. Food Science and Nutrition Journal, 2018; 1-6. DOI: $10.1002 / f s n 3.725$.

Khalafalla, F.A.; Abdel-Atty, N.S.; Abdel-Wanis, S. A. and 
Hanafy, A. S. (2015): Food poisoning microorganisms in chicken broiler meat. Global Veterinaria Journal, 14 (2): 211218.

Lindblad, M.; Lindmark, H.; This te dLambertz, S. and Lindqvist, R. (2006): Microbiological baseline study of broiler chickens at Swedish slaughterhouses. Journal of Food Protection, Vol. 69, No. 12, 2006, Pages 2875-2882.

Marangoni, F.; Corsello, G.; Cricelli, C.; Ferrara, N.; Ghiselli, A.; Lucchin, L. andPoli, A. (2015): Role of poultry meat in a balanced diet aimed at maintaining health and wellbeing: an Italian consensus document. Journal of Food and Nutrition Research; 59:1,27606, DOI: 10.3402/fnr. v59.27606.

Mira, E.K.I. and Eskander, A.A. (2007): Bacteriologic al assessment of freshly slaughtered chicken and trials for improvement. Assiut. Vet. Med. J., 53(113):88-101.

Naaz, A.; Agarwal, N.; Syed, I. and Prasad, R. (2020): A Study on the microbiological quality of raw chicken meat in Dehradun. International Journal of Research in Engineering, Science and Management, Volume-3, Issue-4, pages 25815792.

Nohra, A.; Grinberg, A.; Midwintjjer, A. C.; Marshall,
J. C.; Collins-Emerson, J. M. and French, N. P. (2018): Exposure to whole chicken carcasses may present a greater risk of Campylobacterios is Compared to exposure to chicken drumsticks. Zoonoses and Public Health; 65(7):822830.

https://doi.org/10.1111/zph. 125 05 .

Nossair, M.A.; El Shabasy, N. A.; Hassan, O. S. and Samaha, I. A. (2015): Microbiological status of poultry carcasses from retail outlets in Alexandria province. Journal of Veterinary Sciences 2015, 46: 66-73. DOI: 10.5455/ajvs. 1461.

Oyarzabal, O. A.; Macklin, K. S.; Barbaree, J. M. and Miller, R. S. (2005): Evaluation of agar plates for direct enumeration of Campylobacter spp. from poultry carcass rinses. Applied and Environmental Microbiology Journal, 2005 Jun; 71(6): $\quad 3351-3354 . \quad$ Doi: 10.1128/AEM.71.6.33513354.2005 .

Rani, Z. T.; A. Hugo; C. J. Hugo; P. Vimiso; V. Muche nje (2017): Effect of post-slaughter handling during distribution on microbiological quality and safety of meat in the formal and informal sectors of South Africa: A review. South African Journal of Animal Science 47(3): 255267. 
http://dx.doi.org/10.4314/sajas.v 47i3.2.

Rouger,A.; Tresse,O. and Zagorec, $\quad$ M. (2017): Bacterial Contaminants of Poultry Meat: Sources, Species, and Dynamics. Microorganisms; 5(3):

50.

Doi:10.3390/microorganisms 50

30050 .

Seliwiorstow， T.; Baré, J.; kvens, D. B.; Uyttendaele,I.V. D.M. and De Zutter, L. (2016): Identification of risk factors for Campylobacter contamination levels on broiler carcasses during the slaughter process. International Journal of Food Microbiology, Volume 226, 2 June 2016, Pages 26-32.

Seol, K.; Han, G.; Kim, H. W.; Chang, O.; Oh, M.; Park, B. and Ham, J. (2012): Prevalence and microbial flora of chicken slaughtering and processing procedure. Korean Journal for Food Science of Animal Resources, Vol. 32, No. 6, pp. 763-768 (2012). DOI http://dx.doi.org/10.5851/kosfa. 2012.32.6.763

Shafini, A.B.; Son, R.; Mahyudin, N.A.; Rukayadi, Y. and Tuan Zainazor, T.C. (2017): Prevalence of Salmonella spp. in chicken and beef from retail outlets in Malaysia. International Food Research Journal, 24(1): 437449.
Shaltout, F.A. (2009):

Microbiological quality of chicken carcasses at modern poultry plants. Third Inter. Sci. Conf., 29 Jan. - 1 Feb. / 2009, Benham \& RasSudr, Egypt Fac. Vet. Med. (Moshtohor), Benha Univ.

Sharma, K. P. and Chattopadhyay, U. K. (2015): Assessment of Microbial load of raw meat samples sold in the open markets of city of Kolkata. Journal of Agriculture and Veterinary Science, Volume 8, Issue 3 Ver. I (Mar. 2015), PP 24-27. DOI: 10.9790/238008312427.

Smith, J.E., and Fratamico, P.M. (2005): Diarrhea-inducing Escherichia coli in Foodborne pathogens: handbook microbiology and molecular biology. Caister Academic Press, Norfolk, Uk. 357-382.

Thiessen, G. (2000): Canadian microbiological baseline survey of chicken broiler and young turkey carcasses. Canadian Food Inspection Agency. A62 - 53, pp. 3- 4.

Thomas, N. L. (1978): Observations of the relationship between the surface area and weight of eviscerated carcasses of chickens, ducks and turkeys. Journal of Food Technology. 13:81-86.

U.S. Department of Agriculture - Food Safety and 
Inspection Service (USDA- Yashoda, K.P.; Sachindra, FSIS) (1996): Pathogen N.M.; Sakhare, P. $Z$.and reduction; hazard analysis and Narasimha Rao, D. (2001): critical control point (HACCP) Microbiological quality of systems; final rule. Fed. Regist. broiler chicken carcasses 61:38806- 38989.

Uyas I, İ. A.; İncili, , G. K.; Çakmak, Ö. and Çalıcıoğlu, $M$. (2020): Effect of in-bag carcass decontamination method on shelf life of whole chicken carcasses packaged in plastic bags. Turkish Journal of Veterinary and Animal Sciences, (2020) 44: doi: 10.3906/vet1912-88. processed hygienically in a small scale poultry processing unit. Journal of Food Quality; 24: 249-259.

Zhang, Q., Han, Y., Cao, J., Xu, X., Zhou, G. and Zhang, W. (2012): The spoilage of airpackaged broiler meat during storage at normal and fluctuating storage temperatures. Poultry Science; 91, 208-214.

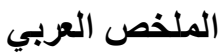

التقيمٍ البكتريولوجي للاجاج اللاحم المتوفر في منافذ البيع في محافظة بورسعيد الليتوري

حني عبداللطيف عبدالرحمن- رنا محمد عمر- هبه محمد علي شاهين

تم فحص 80 عينة من دجاج التسمين الطاز ج و المبرد المجمعةمن محلات الجز ارة و الأسواق

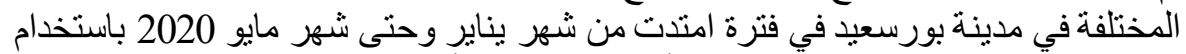

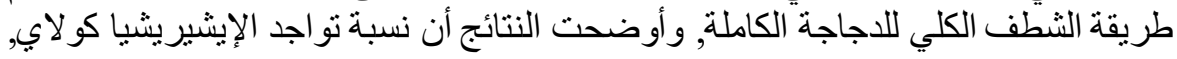

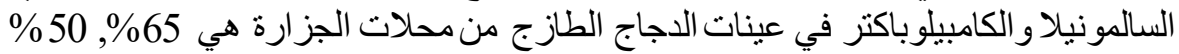

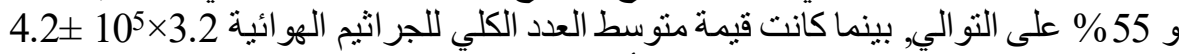

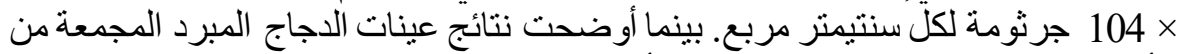

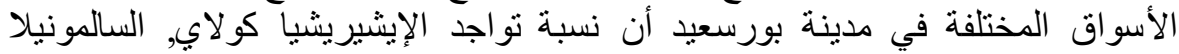

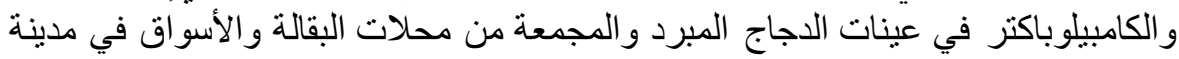

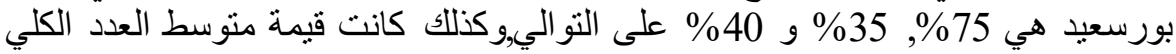

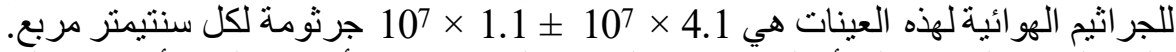

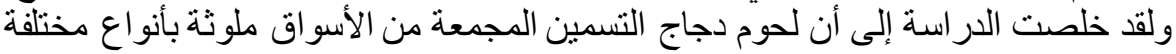

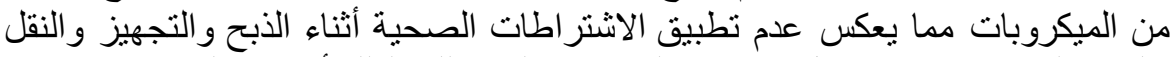

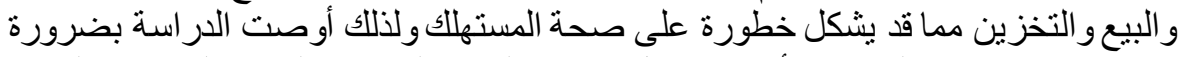
تطبيق الاشتراطات الصحية أثناء مراحل تجهيز الدجاج لتحسين الجودة الميكروبيولولوجية التئية للحم الدجاج وزيادة فترة الصلاحية التية 